\title{
Advanced therapies in complex congenital heart disease
}

\author{
Zoya Rashid and Robert Tulloh *i
}

\begin{abstract}
Background: Although there are some data on how to manage and treat patients with Eisenmenger syndrome due to simple cardiac defects, little evidence exists to guide best management of pulmonary vascular disease in cases with more complex anatomy such as common arterial supply to both the systemic and pulmonary circulations or univentricular physiology. Beyond the uncertainty on how to best assess and manage such patients, there are added concerns with regards to the potential effects of treatment on the risk of cardiac arrhythmia, valve regurgitation and excessive load to the ventricle with increased pulmonary blood flow.
\end{abstract}

Case presentation: We present a case of a patient with double inlet left ventricle and evidence of pulmonary hypertension and describe his outcome on the therapies prescribed.

Conclusions: We review the literature and describe our approach to the patient's management in light of the available evidence and published literature.

Keywords: Pulmonary hypertension, Eisenmenger syndrome, Congenital heart disease, Tadalafil, Bosentan, Macitentan

\section{Background}

Pulmonary arterial hypertension (PAH) describes a group of conditions characterised by a mean pulmonary arterial pressure $\geq 25 \mathrm{mmHg}$, elevated pulmonary vascular resistance and normal left atrial pressure. Eisenmenger syndrome (ES) occurs when any untreated congenital heart disease (CHD) causes severe pulmonary vascular disease and reversal of a systemic-to-pulmonary shunt, with resultant cyanosis [1]. ES can be caused by simple (e.g. atrial or ventricular septal defects) or complex CHD, which includes pulmonary atresia with aorto-pulmonary collaterals, double inlet left ventricle (DILV) and tricuspid atresia with unprotected pulmonary circulation.

The first randomised controlled trial in patients with ES demonstrated haemodynamic and functional improvement following treatment with bosentan in patients with simple defects [2]. There are also data from randomised trials

\footnotetext{
* Correspondence: Robert.Tulloh@bristol.ac.uk
}

Department of Congenital Heart Disease, Bristol Congenital Heart Centre and Biomedical Research Centre, Bristol Heart Institute and Bristol Medical School, Upper Maudlin Street, Bristol BS2 8BJ, UK demonstrating efficacy of the phosphodiesterase-5 inhibitors (PDE5i) sildenafil and tadalafil. These are all summarised in a previous publication [3]. There are, however, increasing data regarding the use of these therapies in patients with PAH associated with complex CHD [4-7].

\section{Case presentation}

Mr. Y was a 53-year-old statistician with a double inlet left ventricle and discordant ventriculo-arterial connection with no pulmonary stenosis. He has never had any intervention but was able to attend university despite being limited in his exercise capacity. Mr. Y was not interested in therapies until after becoming a father of two daughters and realised the importance of being there for them as they grew up.

Mr. Y was limited in his walking, placing him in WHO functional class III but was otherwise relatively well - he did not suffer from pre-syncopal episodes and only occasionally experienced mild haemoptysis. He was deeply cyanosed at rest, and rarely left the house. Before attending the pulmonary hypertension clinic, his main concern

(c) The Author(s). 2020 Open Access This article is licensed under a Creative Commons Attribution 4.0 International License, which permits use, sharing, adaptation, distribution and reproduction in any medium or format, as long as you give appropriate credit to the original author(s) and the source, provide a link to the Creative Commons licence, and indicate if changes were made. The images or other third party material in this article are included in the article's Creative Commons licence, unless indicated otherwise in a credit line to the material. If material is not included in the article's Creative Commons licence and your intended use is not permitted by statutory regulation or exceeds the permitted use, you will need to obtain permission directly from the copyright holder. To view a copy of this licence, visit http://creativecommons.org/licenses/by/4.0/ The Creative Commons Public Domain Dedication waiver (http://creativecommons.org/publicdomain/zero/1.0/) applies to the data made available in this article, unless otherwise stated in a credit line to the data. 
was of troubling ventricular tachycardia. His medication included amiodarone and warfarin only.

The foremost priority, in terms of his management, was control of the cardiac arrhythmia in order to improve his quality of life. Unfortunately, he suffered from the commonly encountered side-effect of thyrotoxicosis from amiodarone therapy, which was refractory to control by medications and ultimately required ablation with radio-crystal therapy. He was also fitted with a subcutaneous implantable cardioverter defibrillator (ICD) but continued to experience syncopal episodes, waking up occasionally on the floor after ICD cardioversion. He had no warning of the episodes and hence no presyncope, suggesting that they were always due to arrhythmia and not to limitation of cardiac output due to high pulmonary vascular resistance.

\section{Examination}

Mr. Y was of slim build, with a BMI of 18.8. He was not visibly short of breath at rest but was cyanosed and exhibited finger clubbing. He had a right ventricular heave and a single loud second heart sound on auscultation. His peripheral oxygen saturations were low, desaturating from 78 to $68 \%$ on exercise and he only managed a 6min walk distance (6MWD) of $180 \mathrm{~m}$.

\section{Investigations}

His electrocardiogram revealed sinus rhythm but with right bundle branch block and periods of ventricular tachycardia (Fig. 1). As expected for a patient with DILV and unprotected pulmonary circulation, Mr. Y had a dilated left ventricle though he maintained moderate dysfunction with a lateral mitral annular plane systolic excursion (MAPSE) of $1.4 \mathrm{~cm}$ and systemic-level pulmonary artery pressures, as expected. Mr. Y was not agreeable to undergoing cardiac catheterisation, but he did undergo cardiac magnetic resonance imaging (Fig. 2). This demonstrated that when in sinus rhythm his ventricular function was moderate (ejection fraction was $42 \%$ ), but this became impaired if there was significant arrhythmia. He had no significant valve disease, with a dilated main pulmonary artery.

\section{Management}

As he had been managing relatively well thus far, a key consideration was whether Mr. Y would benefit from PAH therapy and if so, how this would impact on his cardiac arrhythmia. Might it worsen his left ventricular function by increasing the volume loading to his systemic ventricle and, in turn, his arrhythmias and hence quality of life?

Another consideration was how to monitor his response to therapy, in the presence of a hypoplastic RV and single ventricle physiology? Oxygen saturations were low to begin with $(78 \%)$ and may or may not improve with therapy, as cyanosis within the single ventricle is obligatory. Moreover, his degree of cardiac sarcopenia

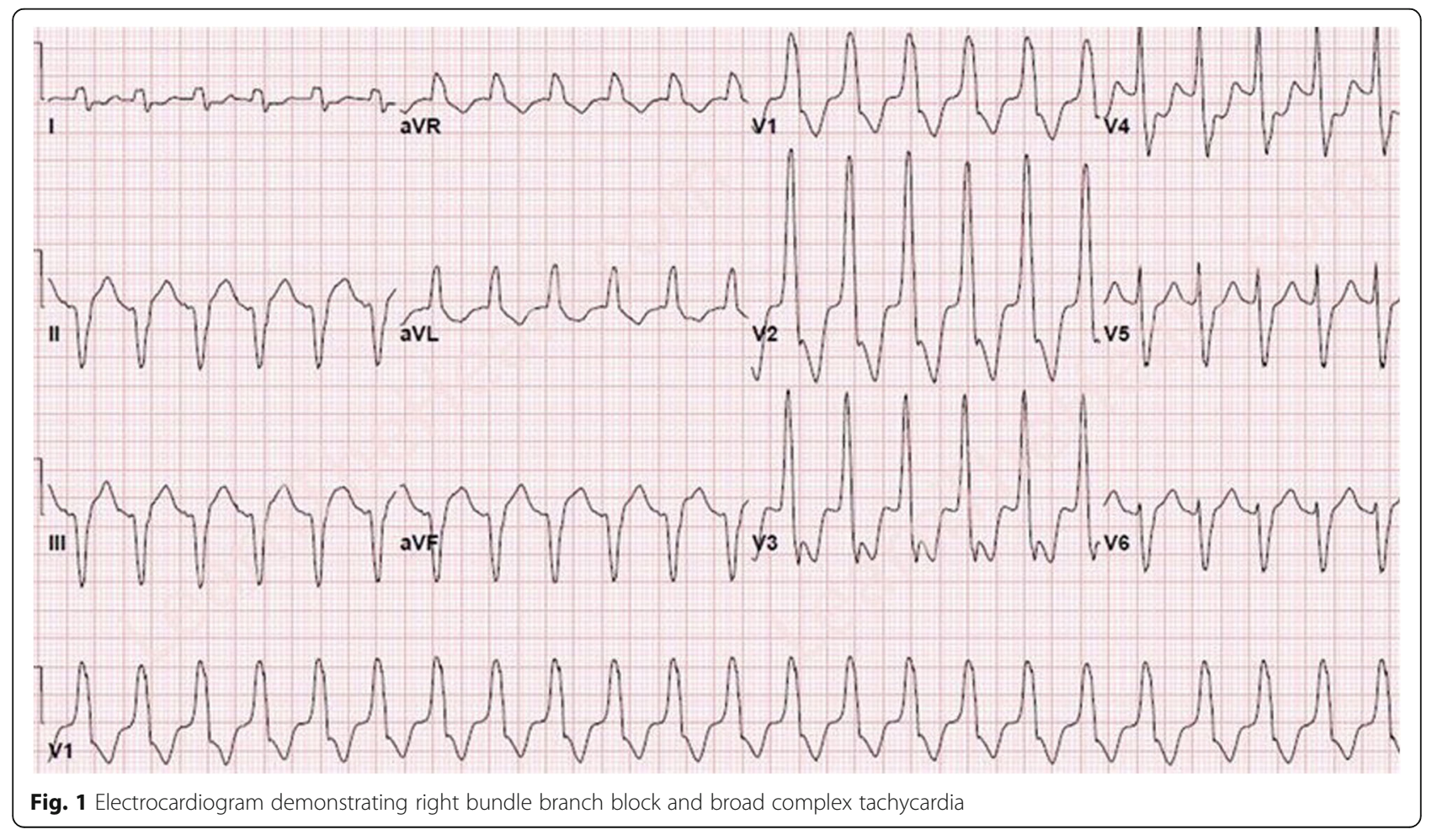




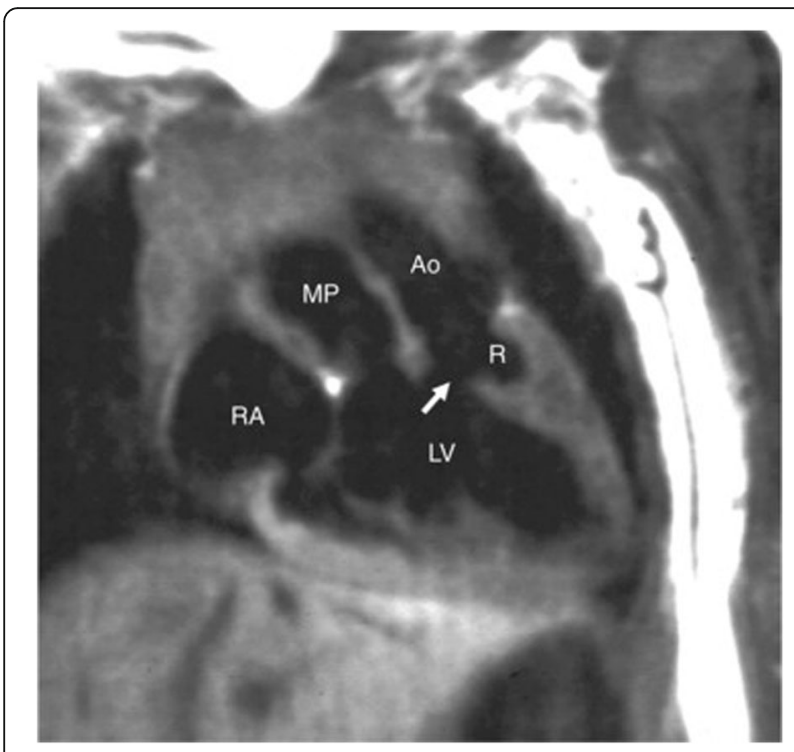

Fig. 2 Magnetic resonance imaging of Mr. Y's cardiac anatomy demonstrating a double inlet left ventricle and ventricular septal defect, with discordant ventriculo-arterial connection

would make it difficult to assess improvement in exercise function.

After discussion with Mr. Y, as well as with other PAH-CHD professionals in the UK and USA, and extrapolating from the BREATHE-5 study [2], Mr. Y was started on the dual endothelin receptor antagonist (ERA) bosentan in 2009. This increased his 6MWD to $250 \mathrm{~m}$ although there was no change in his peripheral oxygen saturation at rest.

He has since moved to a combination of macitentan (ERA) and tadalafil (PDE5i) both of which require once daily administration, in an attempt to further improve his quality of life [8]. Baseline oxygen saturations did not change but the dual therapy resulted in further improvement in his quality of life and he is now able to walk $350 \mathrm{~m}$ in the 6-min walk test. Reassessment of this WHO status was now in class II. His left ventricle function did not deteriorate as assessed visually from echocardiography, nor was there an increase in inflow or outflow valve regurgitation. He suffered from no side effects of therapy, with no increase in gastro-oesophageal reflux, nose bleeds or any further episodes of haemoptysis. He did not have increased arrhythmia, which had been a previous concern.

\section{Discussion and conclusions}

Numerous challenges arise in managing patients with complex CHD, such as paucity of evidence supporting the use of a particular first-line therapy and difficulties monitoring response to therapy due to complex cardiac anatomy. In ES, there is good evidence for the use of bosentan, predominantly from the first trial, published in 2006 [2]. Since then there have been many case series and evidence of improved life expectancy with bosentan. The recent publication on the use of macitentan showed a reduction in pulmonary vascular resistance in the haemodynamic sub-study of patients with ES [9]. In addition, tadalafil has been reported to be effective in ES [10]. However, there remains limited information for the more complex cases, as would be expected with such a diverse range of anatomical substrates. It is likely that optimal therapy will differ case to case in this heterogeneous patient group. However, ERAs show particular promise, both alone and in combination with PDE5is.

\section{Abbreviations \\ 6MWD: 6-Minute walk distance; BMI: Body mass index; CHD: Congenital heart disease; DILV: Double inlet left ventricle; ERA: Endothelin receptor antagonist; ES: Eisenmenger syndrome; ICD: Implantable cardioverter defibrillator; MAPSE: Mitral annular plane systolic excursion; PAH: Pulmonary arterial hypertension; PAH-CHD: Pulmonary arterial hypertension associated with congenital heart disease; PDE5i: Phosphodiesterase-5 inhibitor; PH: Pulmonary hypertension; RV: Right ventricle; TAPSE: Tricuspid annular plane systolic excursion}

\section{Acknowledgements} Not applicable.

\section{About this supplement}

This article has been published as part of Journal of Congenital Cardiology Volume 4 Supplement 1 2020: Unmet needs in Pulmonary Hypertension associated with Adult Congenital Heart Disease (ACHD-PH). The full contents of the supplement are available at https://jcongenitalcardiology. biomedcentral.com/articles/supplements/volume-4-supplement-1.

\section{Authors' contributions}

ZR and RT contributed to the design and writing of the article. All authors have read and approved the final manuscript.

\section{Funding}

Medical writing support was provided by nspm Itd, Meggen, Switzerland. The manuscript was funded by a Medical and Educational Goods and Services (MEGS) grant and Actelion Pharmaceuticals UK Limited (who had no influence on manuscript writing).

Professor Tulloh is supported by the NIHR Biomedical Centre at the University Hospitals Bristol NHS Foundation Trust and the University of Bristol.

\section{Availability of data and materials \\ All data has been shared.}

\section{Ethics approval and consent to participate} Not applicable.

\section{Consent for publication}

Consent was obtained from the patient for their relevant personal and clinical details to be included.

\section{Competing interests}

Professor Robert Tulloh has received unrestricted educational, travel or research grants from Bayer, Pfizer, Actelion and GSK. Zoya Rashid has received a travel grant from Actelion pharmaceuticals.

Received: 12 November 2020 Accepted: 12 November 2020 Published: 16 December 2020

\section{References}

1. Bradford R, Tulloh R. Diagnosis and Management of Pulmonary hypertension in adult congenital heart disease. Br J Cardiac Nurs. 2008;3: $138-45$. 
2. Galie N, Beghetti M, Gatzoulis MA, Granton J, Berger RM, Lauer A, et al. Bosentan therapy in patients with Eisenmenger syndrome: a multicenter, double-blind, randomized, placebo-controlled study. Circulation. 2006; 114(1):48-54.

3. Condliffe R, Clift P, Dimopoulos K, Tulloh RMR. Management dilemmas in pulmonary arterial hypertension associated with congenital heart disease. Pulm Circ. 2018;8(3):2045894018792501.

4. Diaz-Caraballo E, Gonzalez-Garcia AE, Renones M, Sanchez-Recalde A, Garcia-Rio F, Oliver-Ruiz JM. Long-term bosentan treatment of complex congenital heart disease and Eisenmenger's syndrome. Revi Esp Cardiol. 2009;62(9):1046-9.

5. Baptista R, Castro G, da Silva AM, Monteiro P, Providencia LA. Long-term effect of bosentan in pulmonary hypertension associated with complex congenital heart disease. Rev Port Cardiol. 2013;32(2):123-9.

6. Schuuring MJ, Bouma BJ, Cordina R, Gatzoulis MA, Budts W, Mullen MP, et al. Treatment of segmental pulmonary artery hypertension in adults with congenital heart disease. Int J Cardiol. 2013;164(1):106-10.

7. Yamamura K, Nagata H, lkeda K, lhara K, Hara T. Efficacy of bosentan therapy for segmental pulmonary artery hypertension due to major aortopulmonary collateral arteries in children. Int J Cardiol. 2012;161(1):e1-3.

8. Herbert S, Gin-Sing W, Howard L, Tulloh RMR. Early experience of Macitentan for pulmonary arterial hypertension in adult congenital heart disease. Heart Lung Circ. 2017;26(10):1113-6.

9. Gatzoulis MA, Landzberg M, Beghetti M, Berger RM, Efficace M, Gesang S, et al. Evaluation of Macitentan in patients with Eisenmenger syndrome. Circulation. 2019;139(1):51-63.

10. Mukhopadhyay S, Nathani S, Yusuf J, Shrimal D, Tyagi S. Clinical efficacy of phosphodiesterase-5 inhibitor tadalafil in Eisenmenger syndrome--a randomized, placebo-controlled, double-blind crossover study. Congenit Heart Dis. 2011;6(5):424-31.

\section{Publisher's Note}

Springer Nature remains neutral with regard to jurisdictional claims in published maps and institutional affiliations.

Ready to submit your research? Choose BMC and benefit from:

- fast, convenient online submission

- thorough peer review by experienced researchers in your field

- rapid publication on acceptance

- support for research data, including large and complex data types

- gold Open Access which fosters wider collaboration and increased citations

- maximum visibility for your research: over $100 \mathrm{M}$ website views per year

At $\mathrm{BMC}$, research is always in progress.

Learn more biomedcentral.com/submissions 